\title{
Oil and Gas Cooperation between China and Central Asia Gulinaer-Yusufu
}

Professor, Center for Innovation Management Research of Xinjiang (CIM), School of Economics and Management, Xinjiang University

E-mail:gulnur_y@sina.com

Project number: 16BJL101; 010116B02

\section{Keywords: Oil\&Gas; Cooperation; China; Central Asia}

\begin{abstract}
Oil and gas resources are related to China's economic lifeline, but because of the limited geological resources, domestic production has been far from being able to meet consumer demand. In the future, with growing demand for oil and gas, its dependence on imports will continue to grow, foreign dependence on oil resources will increase continuously. As one of the resource-rich regions in the world that has not been fully developed, Central Asia's energy and mineral resources take a more and more important position in the world. China has the unique geopolitical advantage, as well as the wide range of configuration and complementarities with Central Asian countries on energy and petrochemical industrial structure. This paper mainly analyzed the oil and gas cooperation between China and Central Asia.
\end{abstract}

\section{Introduction}

Oil and gas problem is a major strategic issue that related to China's overall social and economic development. It has a direct impact on national security, sustainable development and social stability and plays a very important role in the national economy and social development. In 1993, China became a net oil importer for the first time in its history and in 2003 replaced Japan as the world's second-largest oil importer (after the United States). Two factors have contributed to this rise in energy consumption. With more than 1.3 billion people, China is the most populous county in the world. In late 1978, the Chinese leadership began moving the economy from a sluggish, inefficient, Soviet-style centrally planned system to a more market-oriented system. The result has been a quadrupling of gross domestic product (GDP) since 1978. Measured on a purchasing power parity basis, since 2003, has stood as the second-largest economy in the world, although in per capita terms the country is still poor. The country needs more energy to maintain its spectacular economic performance. In 2015, China’s crude oil and natural gas outputs, imports are summarized by Table1. $^{2}$

\begin{tabular}{|l|l|l|l|l|l|}
\hline country & Crude oil & Oil import & Gas output & \multicolumn{2}{|c|}{ Gas import } \\
\cline { 5 - 6 } & output & & & By pipeline & LNG import \\
\hline China & $214.6 \mathrm{mt}$ & \multirow{2}{*}{$335.8 \mathrm{mt}$} & $138.0 \mathrm{bcm}$ & $33.6 \mathrm{bcm}$ & $26.2 \mathrm{bcm}$ \\
\cline { 4 - 5 } & & & $59.8 \mathrm{bcm}$ & \\
\hline
\end{tabular}

\footnotetext{
${ }^{1}$ Purchasing power parity is the amount of a certain basket of basic goods which can be bought in the given country with the money it produces.

2 http://www.zhgny.org.cn/Detail.aspx?newsId=3845\&TId=343.
} 
Source: BP statistical review of world energy 2016

It is forecasted that China's oil consumption will grow by around 3 percent. By 2020, oil demand will reach about 390 million tons. In the next 20 years, domestic crude oil output will continue to show an upward trend, but the increase will be limited, by 2020, the shortage of oil and gas supply will be about 210 million tons. China's dependence on foreign oil resources will increase from the current level of 40 percent to more than 50 percent.

This study examines China's attempts to satisfy its growing needs for oil and natural gas by increasing imports from close-by producers - Russia and the Central Asia/Caspian Sea region.

It is clear that the energy linkages between Central Asia and the neighbouring major economies have escalated since the break-up of the former Soviet Union in 1991. Early studies from then on, concerning Central Asian hydrocarbon resources, focused mainly on energy investment, transportation to European and Indian sub-continental markets and regional conflicts. Little attention was paid to the logistic nexuses and energy linkages between the region and its eastern neighbours until mid-1997, when China National Petroleum Corporation (CNPC) outbid Amoco, Texaco and Unocal to win two tenders in Western Kazakhstan. Several media sources began their commentaries on the Chinese westward movement and its possible consequences. "Watch out for China”, "China joins the Great Game" and tones of the "Chinese threat" have been widely heard ${ }^{3}$. Geopolitically, Central Asia consists of five countries: Kazakhstan, Kyrgyzstan, Tajikistan, Turkmenistan, and Uzbekistan. Its overall territory covers more than 4 million square kilometres, and the total population is about 60 million people. It has considerable reserves of oil, gas, nonferrous metals, and other mineral resources, and vast irrigated areas and pastures.

Central Asia lies in the hinterland of the Eurasian continent, and the present relationship between China and Central Asia is defined by geographic, political, economic and security factors. Among them the economic factor relationship plays a very important role in the cooperation between China and central Asia. China and the countries in Central Asia have complementary advantages that offer the possibility of extensive cooperation.

China must take effective measures, through political, economic, military, diplomatic and other methods to strengthen the cooperation with Central Asian countries, and take the China-Asia energy channel construction as the strategic focus of China's diplomatic and economic cooperation to guarantee China can get stable, safe and smooth supply of oil and gas.

This paper mainly analyzed the oil and gas linkages between Central Asia and China and the sequential implications. Priority is given to the oil and gas links between the Central Asian countries (principally Kazakhstan, Uzbekistan and Turkmenistan) and China, with special emphasis on the geopolitical and economic importance of the region's oil and gas to China in the next decade.

\section{Oil and gas resources in central Asia}

Kazakhstan is a very important country of Central Asia. There are more than 200 existing oil and gas fields in Kazakhstan, mostly in its western region, oil and gas reserves are mainly located in the western Atyrau states, where the 75 existing oil fields, about 10 million tons of proven oil reserves.

Since 2000, Kazakhstan has experienced significant economic growth. Two of the main catalysts for this growth are economic reform and foreign investment, much of which has been concentrated in the energy sector. Exports of crude oil have grown significantly and Kazakhstan is

\footnotetext{
${ }^{3}$ Holley, 1997; Dow Jones News, 1997
} 
the second largest oil producer (after Russia) among the former Soviet republics. Kazakhstan posessed the Caspian region's largest recoverable crude oil reserves. Kazakhstan has increased its capacity of oil and gas production since last decade. The amount of oil and gas resources in Kazakhstan are roughly summarized by Table $2^{4}$.

\begin{tabular}{|l|l|l|l|l|}
\hline country & Oil reserve & Oil export & Gas reserve & $\begin{array}{l}\text { Gas export } \\
\text { (By pipeline) }\end{array}$ \\
\hline Kazakhstan & $3900 \mathrm{mt}$ & $66.6 \mathrm{mt}$ & $900 \mathrm{bcm}$ & $11.3 \mathrm{bcm}$ \\
\hline
\end{tabular}

Source: BP statistical review of world energy 2016

Kazakhstan's oil reserves represents $3 \%$ of total world reserves, proven natural gas reserves represent $1 \%$ of total world reserves. It has more viable option to export its oil and gas than other countries of the Central Asia. It also has an option to export oil and gas to the West across Caspian Sea via Azerbaijan. Another option is newly constructed, export to East towards China. China is one of the largest oil and gas consumer market of the world. Kazakhstan is able to access direct market in China that is the more viable option than others. Kazakhstan has more potentiality for foreign oil companies to invest in its oil and gas sectors. ${ }^{5}$

2.2 Oil and gas resources in Uzbekistan

Uzbekistan is a double landlocked country in Central Asia. It shares border with Kazakhstan in the West, Kyrgyzstan in the North, Tajikistan in the East and Afghanistan and Turkmenistan in the South. Uzbekistan is abundant in production of cotton, gold, uranium and natural gas. The economic policies of Uzbekistan have repelled foreign investment. Despite of this, natural gas reserves of Uzbekistan large in amount made it very attractive country for the Western countries. Uzbekistan's Oil and Gas is one of the prime industries in the energy sector. There are more than 171 oil and gas fields. Most of them are concentrated in the Fergana valley region. $60 \%$ of the Uzbekistan oil and gas fields are concentrated in the Bukhara and the Kiev region. Huge reserves of oil are found in Uzbekistan. Currently it possesses about 600 million barrels of oil reserve. New oil fields have been explored in south western Uzbekistan in places like Kokdumalak, Shurtan, Olan, Urgin and South-Tandirchi. The Ustyurt plateau and the Aral Sea also have substantial oil deposits. The largest oil reserves in Uzbekistan are located in the Ustyurt Region. In total there are 52 natural gas fields. Gazli, Shurtan, Pamuk, and Khauzak are the major oil fields. The amount of oil and gas resources in Uzbekistan are roughly summarized by Table $3^{6}$

\begin{tabular}{|l|l|l|l|l|}
\hline country & Oil reserve & Oil export & Gas reserve & $\begin{array}{l}\text { Gas export } \\
\text { (By pipeline) }\end{array}$ \\
\hline Uzbekistan & $100 \mathrm{mt}$ & $0.2 \mathrm{mt}$ & $110 \mathrm{bcm}$ & $7.5 \mathrm{bcm}$ \\
\hline
\end{tabular}

Source: BP statistical review of world energy 2016

2.3 Oil and gas resources in Turkmenistan

\footnotetext{
${ }^{4}$ The figures come from BP Statistical Review of World Energy, June 2010 and CIA World Fact Book 2011.

${ }^{5}$ Kazakhstan oil and gas tax guide http://www.ey.com/Publication/vwLUAssets/Kazakhstan-oil-and-gas-tax-guide-2010-E/\$FIL E/Kazakhstan-oil-and-gas-tax-guide-2010-E.pdf page 6

6 The figures come from BP Statistical Review of World Energy, June 2010 and CIA World Fact Book 2011.
} 
Turkmenistan also known as Turkmen is a country of Central Asia. It shares border with Afghanistan in the Southeast, Iran in the South, Uzbekistan in the East and Kazakhstan in the north and northwest and the Caspian Sea in the West. It is wealthy in natural resources. The Turkmenistan Natural Gas Company (Turkmengaz), under the auspices of the Ministry of Oil and Gas, controls the gas extraction in the republic. Gas production is the youngest and most dynamic and promising sector of the national economy. The Ministry of Oil and Gas oversees exploration of new deposits. Sites under exploration are located in Mary Province, in western and northern Turkmenistan, on the right bank of the Amu Darya, and offshore in the Caspian Sea.

Most of Turkmenistan's oil is extracted from fields at Koturdepe, Nebitdag, and Chekelen near the Caspian Sea, which have a combined estimated reserve of 700 million tons. The oil extraction industry started with the exploitation of the fields in Chekelen in 1909 and Nebitdag in the 1930, then production leaped ahead with the discovery of the Kumdag field in 1948 and the Koturdepe field in 1959. All the oil produced in Turkmenistan is refined in Turkmenbashy. ${ }^{7}$

The amount of oil and gas resources in Uzbekistan are roughly summarized by Table $4^{8}$

\begin{tabular}{|l|l|l|l|l|}
\hline country & Oil reserve & Oil export & Gas reserve & $\begin{array}{l}\text { Gas export } \\
\text { (By pipeline) }\end{array}$ \\
\hline Turkmenistan & $100 \mathrm{mt}$ & $6.3 \mathrm{mt}$ & $17500 \mathrm{bcm}$ & $38.1 \mathrm{bcm}$ \\
\hline
\end{tabular}

Source: BP statistical review of world energy 2016

\section{Oil and gas cooperation between China and central Asia}

On February 22, 2011, witnessed by Chinese President Hu Jintao and Kazakh President Nursultan Nazarbayev, CNPC inked an agreement in principal with KazMunay Gas on the cooperation project at Urikhtau in Kazakhstan. According to the agreement, the two parties will establish a joint venture on equal equities to jointly develop the Urikhtau gas field, which will secure the gas supply for the phase- II Kazakhstan-China Gas Pipeline. ${ }^{9}$ According to October 14, 2009 the PRC Government and the Government of Kazakhstan signed the intergovernmental agreement, and June 12, 2010 Kazakhstan national oil and gas stock company of China National Petroleum Corporation signed agreement between the relevant enterprises, project completed a technology demonstration program and create a joint venture agreement negotiations and other preparatory work.

The "win-win, long-term cooperation," between China and Kazakhstan, on the one hand to meet the country's economic development and people's living needs, on the other hand the gas and oil will be exported to China through Central Asia Gas Pipeline. This plays an important role in increasing oil production and economic benefits. Pipeline is completed; Central Asia and Kazakhstan natural gas pipeline to gas trunk network and connectivity of the western major oil and gas areas effectively enhance oil and gas cooperation between the two countries. ${ }^{10}$ The most recent agreement was the 《Joint Declaration on the new phase about the comprehensive strategic partnership between People's Republic of China and Republic of Kazakhstan》signed in August 2015. The main contents are as follows: The two countries will continue to expand and deepen energy cooperation, carry out new cooperation projects in oil and gas exploration and development, oil processing and other fields, expand Kazakhstan's energy exports to China under the principle of

\footnotetext{
${ }_{8}^{7}$ http://countrystudies.us/turkmenistan/22.htm

8 The figures come from BP Statistical Review of World Energy, June 2010 and CIA World Fact Book 2011.

9 http://www.cnpc.com.cn/en/press/newsreleases/Newoilandgascooperationagreement_signedbetweenChinaandKazakhstan.htm

10 http://en.careallgroup.com/Article/?id=73
} 
mutual benefit. The energy cooperation between Chinese government and the Kazakhstan government can be summarized by table 3-1.

Table 5 Oil and Gas Relationship between Chinese and Kazakhstan Government

\begin{tabular}{|c|c|}
\hline Time & Contents of the Agreement \\
\hline $\begin{array}{l}\text { September, } 1 \\
\quad 997\end{array}$ & $\begin{array}{l}\text { 《Cooperation agreement between China and Kazakhstan in the field } \\
\text { of oil and gas》 }\end{array}$ \\
\hline May,2004 & $\begin{array}{l}\text { 《The basic principles agreement on Atasu Kazakhstan to Alashankou } \\
\text { China oil pipeline construction》 and 《The framework agreement on the } \\
\text { full cooperation in the field of oil and gas between Chinese } \\
\text { government and Kazakhstan government》 etc }\end{array}$ \\
\hline $\begin{array}{l}\text { August,200 } \\
5\end{array}$ & $\begin{array}{l}\text { 《Feasibility tudy on Natural Gas Pipeline Project between China and } \\
\text { Kazakhstan》 }\end{array}$ \\
\hline $\begin{array}{c}\text { August, } 200 \\
7\end{array}$ & $\begin{array}{l}\text { 《Second phase construction and operation agreement of China and } \\
\text { Kazakhstan crude oil pipeline》 }\end{array}$ \\
\hline April,2009 & A series of bilateral oil and gas cooperation framework agreement \\
\hline June,2011 & $\begin{array}{l}\text { 《Joint Declaration on the comprehensive strategic partnership } \\
\text { between People's Republic of China and Republic of Kazakhstan》 }\end{array}$ \\
\hline $\begin{array}{c}\text { September, } 2 \\
013\end{array}$ & $\begin{array}{l}\text { 《Joint Declaration on Further Deepening the Strategic Partnership } \\
\text { between China and Kazakhstan》 }\end{array}$ \\
\hline $\begin{array}{l}\text { August,201 } \\
\quad 5\end{array}$ & $\begin{array}{l}\text { 《Joint Declaration on the new phase about the comprehensive } \\
\text { strategic partnership between People's Republic of China and Republic } \\
\text { of Kazakhstan》 }\end{array}$ \\
\hline
\end{tabular}

Source: Sorted out according to the book "Central Asia Energy and Great Power Game” written by Zhang Ning and some follow-up information

The energy cooperation between China and Central Asia at the enterprise level, mainly achieved by the cooperation between China National Petroleum Corporation and Kazakhstan national oil and gas company. The main mode of cooperation is to establish the joint ventures or acquisition of shares. The cooperation between the two parties can be summarized by Table 6 .

Table 6 Enterprise Project Cooperation between China and Kazakhstan

\begin{tabular}{|c|c|}
\hline Name of the Project & Contents of cooperation \\
\hline Aktobe Project & $\begin{array}{l}\text { In June } 1997 \text {, Petro China purchased } 60.28 \% \text { stake ofAktobe } \\
\text { Oil \& Gas Inc. In 2003, purchased } 25.12 \% \text { stake. At this point, } \\
\text { Petro China's share reached up to } 85.4 \% \text {. The oil produced by } \\
\text { the oil field is all exported to China through the } \\
\text { China-Kazakhstan crude oil pipeline. }\end{array}$ \\
\hline (North Buzachi) & $\begin{array}{l}\text { In October } 2003 \text {, CNPC purchased } 35 \% \text { and } 65 \% \text { equity of } \\
\text { North Buzzac Oilfield in northwestern Kazakhstan, with a final } \\
\text { shareholding of } 100 \% \text {. }\end{array}$ \\
\hline $\begin{array}{l}\text { China-Kazakhstan } \\
\text { crude oil pipeline }\end{array}$ & $\begin{array}{l}\text { In July 2004, China and Kazakhstan each } 50 \% \text { of the shares set } \\
\text { up a "Sino-Kazakhstan pipeline limited liability company" } \\
\text { through equity participation of } 50 \% \text { each, responsible for the } \\
\text { Sino-Kazakhstan crude oil pipeline project investment }\end{array}$ \\
\hline
\end{tabular}




\begin{tabular}{|c|c|}
\hline & construction, pipeline operations and other business. \\
\hline PK Project & $\begin{array}{l}\text { In October 2005, CNPC acquired Kazakhstan International Oil } \\
\text { Company "PK", the company's oil and gas fields in } \\
\text { Kazakhstan, refineries and other assets. In July 2006, 33\% of } \\
\text { the shares of "PK" were transferred to Kazakhstan National Oil } \\
\text { Company with a final shareholding of } 67 \% \text {. }\end{array}$ \\
\hline Kashagan Project & $\begin{array}{l}\text { At the end of October 2013, Petro China acquired } 8.33 \% \text { of } \\
\text { Kazakhstan's largest offshore oil field and the world's fifth } \\
\text { largest oil field, the Kashagan Oilfield, to become the sixth } \\
\text { largest shareholder of the oil field. }\end{array}$ \\
\hline $\begin{array}{c}\text { Chimkent Refinery } \\
\text { Project }\end{array}$ & $\begin{array}{l}\text { In January 2014, PetroChina participated in the modernization } \\
\text { project of the Chimkente Refinery, which held } 50 \% \text { of the } \\
\text { shares. After the project was put into operation, it would } \\
\text { produce the gasoline and diesel oil with the quality of Euro IV } \\
\text { and Euro V, which would ease the gap of Kazakhstan's } \\
\text { refined oil shortage, especially high-grade gasoline shortage. }\end{array}$ \\
\hline $\begin{array}{l}\text { Large caliber pipe } \\
\text { factory construction } \\
\text { project }\end{array}$ & $\begin{array}{l}\text { In September 2015, China and Kazakhstan signed the } \\
\text { agreement on the establishment of "Asian Steel Pipe Co., Ltd. } \\
\text { joint venture framework agreement" to construct a large } \\
\text { diameter pipe plant in Kazakhstan Almaty Industrial Park, the } \\
\text { total value of the project is more than } 100 \text { million US dollars. }\end{array}$ \\
\hline
\end{tabular}

Source: Sorted out according to the relevant information

Since 2012, China has begun to import natural gas from Uzbekistan, so that China - Central Asia gas pipeline to play a full role. As of 2014, CNPC has carried out three major projects in Uzbekistan, namely: Mingbulak Project, The Aral sea blocks project, Silk Road project.

Investment cooperation is actively developed in the fields of oil and gas, and mining. For example, In 2010 China National Petroleum Corporation (CNPC), the country's largest oil and gas producer signed an agreement with the national oil company of Uzbekistan to buy 10 billion cubic meters of natural gas per year. A spur to the Turkmenistan-to-China pipeline, which sent $4 \mathrm{bcm}$ of natural gas to China in 2010, is under consideration to pump Uzbekistan's own natural gas to the PRC $^{11}$. In December 2010, the Asia Trans Gas Uzbek-Chinese joint venture created by Uzbekneftegaz and the CNPC opened the second strand of Uzbek section of the Turkmenistan-to-China gas pipeline. It allowed the flow of LNG to the PRC through the pipeline to reach its expected annual level of $15 \mathrm{bcm}$ in $2011^{12}$. These volumes met half of the PRC's annual demand for imported $\mathrm{LNG}^{13}$. The CNPC is helping to explore and develop other Uzbek oil and gas fields, including those in the Aral Sea, Ustyurt, Bukhara-Khiva and Ferghana Valley ${ }^{14}$.The commissioning of the Central Asia-China pipeline has opened new opportunities for cooperation in the energy sector. Both countries take active measures to connect Uzbekistan's gas transmission system with the China-Uzbekistan gas pipeline.

\footnotetext{
11 The Times of Central Asia, January 7

12 UzReport.com, December 29, 2010

13 The Times of Central Asia, December 27, 2010

14 Ministry of Finance of the Republic of Uzbekistan, June 15, 2010,
} 
The China/Uzbekistan gas line is part of the 1,800-km China/Central Asia gas pipeline---the China's first large pipeline project to import natural gas that opened in December 2009, linking gas fields in Turkmenistan, Uzbekistan and Kazakhstan to northwest China's Xinjiang region. ${ }^{15}$

At Horgos in Xinjiang, the pipeline is connected with China's second West-East gas pipeline, which extends 8,653 km across 14 provinces, municipalities and regions, including Shanghai and Hong Kong.

With the rapid increase in natural gas consumption in China, the country is expected to see more gas imports in the future. ${ }^{16}$

Energy cooperation level between China and Uzbekistan mainly in the field of government cooperation, and there are still some cooperation under enterprise level.The Government level energy cooperation between China and Uzbekistan can be summarized by table 7

Table 7 Energy cooperation between China and Uzbekistan

\begin{tabular}{|c|c|}
\hline Time & Contents of cooperation \\
\hline June, 2004 & $\begin{array}{l}\text { 《Joint Statement on Further Developing and Deepening the } \\
\text { Friendly Partnership between China and Uzbekistan》 }\end{array}$ \\
\hline May, 2005 & $\begin{array}{c}\begin{array}{c}\text { Friendship and Cooperation Treaty between China and } \\
\text { Uzbekistan }\rangle_{0}\end{array} \\
\end{array}$ \\
\hline June, 2012 & $\begin{array}{l}\text { President of Uzbekistan Karimov attended the Shanghai } \\
\text { Cooperation Organization Beijing summit and indicated that the } \\
\text { relations between the two countries have risen to strategic } \\
\text { partnerships. }\end{array}$ \\
\hline $\begin{array}{l}\text { September, } \\
2013\end{array}$ & $\begin{array}{l}\text { 《Treaty of Friendship and Cooperation between the People 's } \\
\text { Republic of China and the Republic of Uzbekistan》 }\end{array}$ \\
\hline August, 2014 & $\begin{array}{l}\text { 《Joint Declaration of the People 's Republic of China and the } \\
\text { Republic of Uzbekistan》 }\end{array}$ \\
\hline June, 2016 & $\begin{array}{l}\text { 《Joint Statement of the People's Republic of China and the } \\
\text { Republic of Uzbekistan》 }\end{array}$ \\
\hline
\end{tabular}

Source: Sorted out according to the book "Central Asia Energy and Great Power Game” written by Zhang Ning and some follow-up information

The enterprise level energy cooperation between China and Uzbekistan can be summarized by table 8:

Table 8 Enterprise Cooperation Project between China and Uzbekistan

\begin{tabular}{cl}
\hline Name of the project & \multicolumn{1}{c}{ Contents of the cooperation } \\
\hline Mingbulak project & $\begin{array}{l}\text { Since October 2011, Petro China has carried out Geological } \\
\text { Exploration in Uzbekistan and oil\& gas production in } \\
\text { Migbulak Oilfield. }\end{array}$ \\
\hline Gas pipeline D line & $\begin{array}{l}\text { In August 2014 Petro China and Uzbekistan National Oil } \\
\text { Company signed the Agreement of "China - Uzbekistan }\end{array}$ \\
\hline
\end{tabular}

\footnotetext{
${ }^{15}$ Detailes in WanZhihong “CNPC inks deal with Uzbekistan” China Daily, June 10, 2010, available online at http://www.chinadaily.com.cn/business/2010-06/11/content_9964779.htm

16 http://www.theenergyreport.com/pub/na/6567
} 
natural gas pipeline D line between enterprises".

Mubarak natural In August 2014, Petro China and Uzbekistan National Oil

gas chemical plant Company signed the " Mubarak Natural Gas Chemical Plant

Cooperation Memorandum o". Petro China builds natural gas

chemical plants on the basis of the Mubarak natural gas

treatment plant in Uzbekistan, producing products such as

polyethylene and liquefied petroleum gas for the Central Asian market.

\section{Source: Sorted out according to the relevant information}

China had imported 7 billion cubic meters of natural gas from 2012 to 2015, the average annual import was 1.75 billion cubic meters. This can be shown in figure 1.

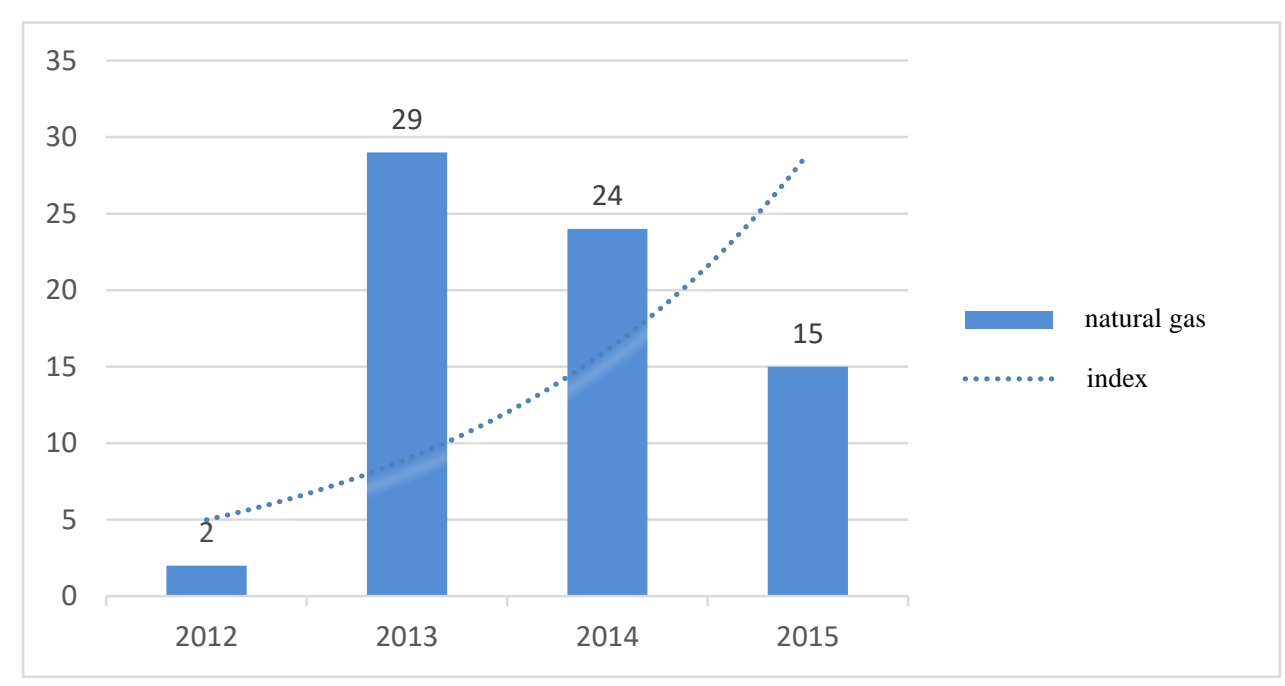

Figure1 Imported natural gas from UzbekistanUnit: 100 million cubic meters

China has become the largest natural gas importer of Uzbekistan, dependency of Uzbekistan oil and gas resources exports to China can be summarized by table 9 .

Table 9 Dependency of Uzbekistan oil and gas resources exports to China

\begin{tabular}{cccc}
\hline Year & $\begin{array}{c}\text { Total exports of oil and gas } \\
\text { resources in Uzbekistan } \\
\text { (million dollars) }\end{array}$ & $\begin{array}{c}\text { Uzbekistan 's oil and gas exports } \\
\text { to China (million dollars) }\end{array}$ & $\begin{array}{c}\text { Percentage of Oil } \\
\text { and gas exports } \\
\text { to China (\% }\end{array}$ \\
\hline 2010 & 541.2 & 30.3 & 7.3 \\
\hline 2011 & 1543.1 & 159.4 & 20 \\
\hline 2012 & 562.3 & 2064 & 84.4 \\
\hline 2013 & 2446 & 1758 & 84.4 \\
\hline 2014 & 2085.3 & & 28.4 \\
\hline
\end{tabular}

Sourse: United Nations Conference on Trade and Development (UNCTAD) database, http://unctad.org/en/Pages/Statistics.aspx

China has won a multi-billion deal to develop gas concessions in Turkmenistan. In April 2006, China and Turkmenistan signed an agreement in which Turkmenistan would sell natural gas to China and China would help Turkmenistan build a pipeline to deliver it. China has been invited to develop Bolivian gas field. ${ }^{17}$

\footnotetext{
${ }^{17}$ http://factsanddetails.com/china.php?itemid=1727\&catid=13\&subcatid=85
} 
In 2007, China and Turkmenistan signed a framework agreement to transport 30bcm a year over thirty years, starting in 2009, through a seven-thousand-kilometer dual pipeline system running from Turkmenistan's Bagtyarlik field through Uzbekistan and Kazakhstan to western China. ${ }^{18}$ CNPC was given a lease to explore and extract gas in the Bagtyarlik area, and the deal provided that, in addition to funding and building the pipeline, the Chinese company would provide technical assistance for constructing and maintaining the pumping stations and compression systems.

The most recent agreement was the "Joint Statement on Further Developing and Deepening the Friendly Partnership between China and Turkmenistan” signed in May 2014. The main contents are: On the basis of equality and mutual benefit, the two parties ensure that China-Central Asia Gas Pipeline A , B, C line be in smooth and stable operation and in full supply of gas, to start the building of $\mathrm{D}$ line as soon as possible.

The enterprise level energy cooperation between China and Turkmenistan can be summarized as: (see table 10)

Table 10 Oil and gas cooperation between China and Turkmenistan

\begin{tabular}{|c|c|}
\hline Time & Contents of cooperation \\
\hline July,2000 & 《Joint Statement of the People 's Republic of China and Turkmenistan》 \\
\hline April,2006 & $\begin{array}{l}\text { 《General Agreement on the Implementation of China-Turkmenistan } \\
\text { Natural Gas Pipeline Project and Turkmenistan's Sale of Natural Gas to } \\
\text { China》 }\end{array}$ \\
\hline July,2007 & $\begin{array}{l}\text { 《Joint statement on further consolidating and developing friendly } \\
\text { relations between the two countries》 }\end{array}$ \\
\hline $\begin{array}{l}\text { August,200 } \\
\quad 8\end{array}$ & $\begin{array}{l}\text { China and Turkmenistan once again signed a framework for expanding } \\
\text { the } 100 \text { billion square gas cooperation }\end{array}$ \\
\hline $\begin{array}{c}\text { November,2 } \\
011 \\
\end{array}$ & $\begin{array}{l}\text { 《Joint Statement on Comprehensive and Deepening Sino - Japanese } \\
\text { Friendship and Cooperation》 }\end{array}$ \\
\hline $\begin{array}{l}\text { September,2 } \\
013\end{array}$ & $\begin{array}{l}\text { 《Joint Declaration on the Establishment of Strategic Partnership } \\
\text { between China and Turkmenistan》 }\end{array}$ \\
\hline May,2014 & $\begin{array}{l}\text { 《Joint Declaration on the Development and Deepening of Strategic } \\
\text { Partnership between China and Turkmenistan》 }\end{array}$ \\
\hline
\end{tabular}

Source: Sorted out according to the book "Central Asia Energy and Great Power Game” written by Zhang Ning and some follow-up information

Sino-Turkish cooperation between enterprises is different from Sino-Kazakh cooperation, CNPC participated in Turkmenistan's energy development projects, as well as provided the technical services to Turkmenistan. This can be summarized by table 11:

Table 11 Enterprise Cooperation Project between China and Turkmenistan

\begin{tabular}{cl}
\hline Name of the project & \multicolumn{1}{c}{ Contents of cooperation } \\
\hline Amu Darya project & $\begin{array}{l}2007 \text { - 2009 CNPC implemented the development project of } \\
\text { the natural gas field on the right bank of the Amu River in the } \\
\text { territory of the country and be responsible for the construction } \\
\text { of a gas pipeline in China. }\end{array}$ \\
\hline
\end{tabular}

\footnotetext{
${ }^{18}$ Details in Le Tian, “Turkmenistan Energy Deals Signed,” China Daily, July 18, 2007, available online at http://www.chinadaily.com.cn/china/2007-07/18/content_5438174.htm; Daniel Kimmage, “Central Asia: Turkmenistan-China Pipeline Project Has Far-Reaching Implications,” Radio Free Europe/RadioLiberty, April 10, 2006, available online at http://www.rferl.org/content/article/1067535.html.
} 
Source: Sorted out according to the relevant information

From 2010 to 2015, China had imported 1166.5 billion cubic meters of natural gas, the average annual import was 19.44 billion cubic meters. The supply of natural gas showed a steady and gradual upward trend. This can be shown in figure 2.

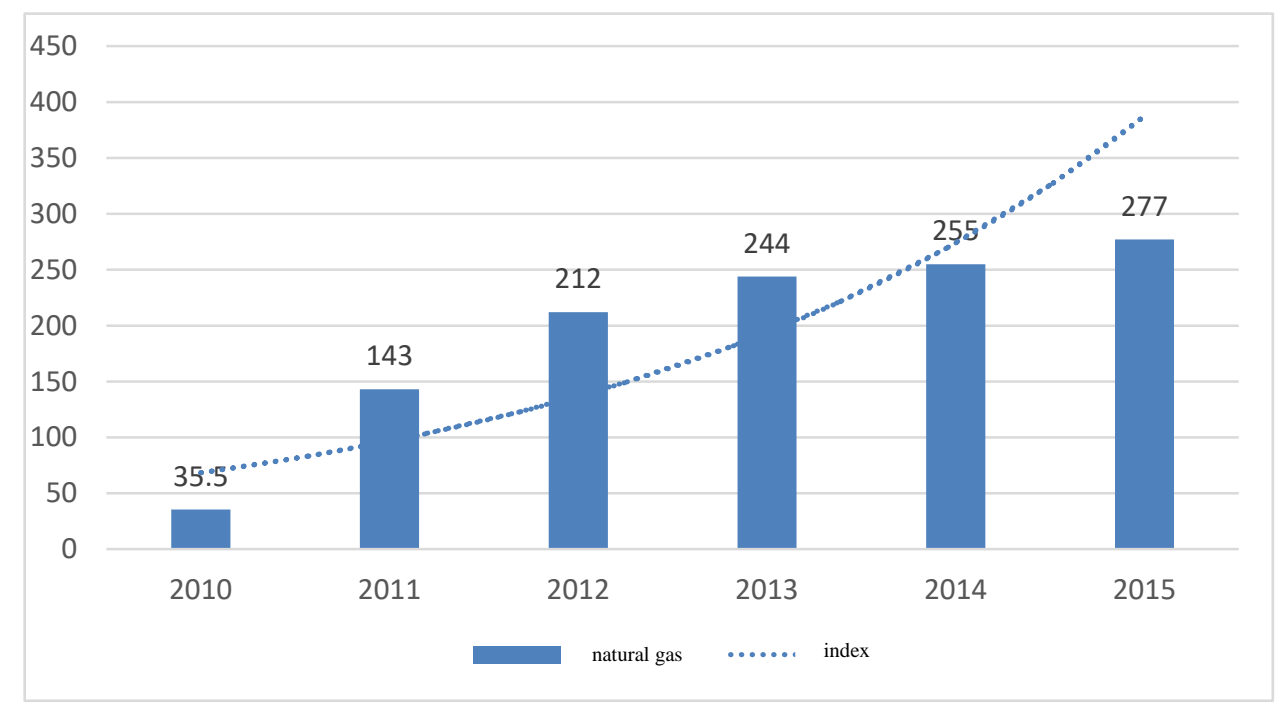

Figure1 Imported natural gas from TurkmenistanUnit: 100 million cubic meters

China has become the first largest natural gas importer of Turkmenistan, dependency of Turkmenistan oil and gas resources exports to China can be summarized by table 12 .

Table 12 Dependency of Turkmenistan oil and gas resources exports to China

\begin{tabular}{cccc}
\hline Year & $\begin{array}{c}\text { Total exports of oil } \\
\text { and gas resources in }\end{array}$ & $\begin{array}{c}\text { Uzbekistan 's oil and gas } \\
\text { exports to China }\end{array}$ & $\begin{array}{c}\text { Percentage of } \\
\text { Oil and gas }\end{array}$ \\
\hline 2010 & 33973 & 1235.5 & 36.3 \\
\hline 2011 & 9548.9 & 5122.5 & 53.6 \\
\hline 2012 & 12986 & 7874.4 & 60.6 \\
\hline 2013 & 12932 & 8689.7 & 67.2 \\
\hline 2014 & 13750 & 9323.1 & 67.8 \\
\hline
\end{tabular}

Sourse: United Nations Conference on Trade and Development (UNCTAD) database, http://unctad.org/en/Pages/Statistics.aspx

3.2 Strategic fit: "going out" and "energy rejuvenating."

China's economic development needs the rich energy of Central Asian countries, energy export of Central Asia also needs China can beits export market as a springboard of linking East Asia market. From the market location point of view, China is the largest in eastern Central Asia oil and gas market. China's achievements in reform and development is enhancing the China's position in international trade, also raising the national economy and the vitality of the China's domestic market. Thus, for the Central Asian countries, the China's market has a great appeal and potentiality; to develop the cooperation with China means of Central Asia oil and gas energy will provide a direct channel exports to East Asia. It can be said that to deepen energy cooperation is a win-win strategy of mutual interest.

\subsection{China’s energy development strategy}

China is implementing international energy development strategy. China's energy development investment policy is to make full use of domestic and international markets, and implement "bringing in" and "going out" energy development strategy. In 21st century, China actively built an energy development strategy of oil security as the core content. In March 2001, introduced the 
program with the topic as "China's 21st Century Oil Strategy" 19the overall framework of the program constituted by 10 areas: (1) to achieve diversification strategy; (2) to implement going out strategy and open foreign oil and gas fields jointly; (3) to establish national oil reserve system and oil security system; (4) to explore the establishment of a national oil fund, to build the oil financial system and the global oil futures market; (5) to explore the establishment of "National Energy Commission"; (6) to build transport fleet and establish strong naval and air forces, let them have thecapacity of defending China's maritime resources and energy supply; (7) to establish Xinjiang, Shanxi, Gansu, and Ningxia--- four strategic reserves of oil and gas fields; (8) to accelerate the establishment of saving oil consumption patterns; (9) to develop the Sinopec, Petro China and CNOOC three oil carriers; (10) toadjust the national energy structure, establish the natural gas and coal consumption system diversification strategy.

\subsection{Central Asia's energy development strategy}

\subsubsection{Oil and gas development strategy of Kazahkstan}

Oil industry is the country's long-term and priority development objective. Specific strategies include: increasing efforts to attract foreign investment, making full use of foreign advanced technology to develop their own oil industry; developing multi-dimensional oil export pipeline construction, preventing dependence on a country, speeding up their infrastructure, increasing oil processing capacity to ensure domestic demand, improving export capacity and added value of the products.

Kazakhstan has already considered the development of oil and gas sector as the most important factor of the development of national economy. Oil and gas sector has become the most promising department of economic development in Kazakhstan since 1980's. In "National economic development strategy of Kazakhstan, 2030", Kazakhstan clearly described three main directions of the development of energy sector: First, relying on large multinational oil companies, to attract the whole Chinese business community, large-scale investment and the world's better technology to its oil and gas projects, to move Kazakhstan towards the world energy market as soon as possible. Kazakhstan should speed up and use its oil and gas reserves effectively, in this way attract wealthy Chinese partners. Second, to expand and develop the oil pipelines system, which not only expand Kazakhstan's oil exports, but also increase its oil production. Third, to make use of aims of developing national fuel energy strategy, increase the world powers interest to the global significance of Kazakhstan's energy supplies.

\subsubsection{Oil and gas development strategy of Turkmenistan}

Turkmenistan pays much attention to introduction of modern technologies, equipment and services as well as to long term cooperation with foreign companies in addressing large scale tasks set forth in the National Program "Strategy of Turkmenistan's oil and gas sector development until 2020". The program envisaged that production of oil and gas condensate will grow up to 48 million tons, and gas extraction - up to 120 billion cubic meters. By 2020, the production is expected to rise up to 100 million tons and 240 billion cubic meters accordingly.

The accomplishment of such a large scale tasks require development of the logistic base of industries, expansion of transport infrastructure and realization of transnational pipeline projects.

Foreign companies operating in close partnership with Turkmenistan's oil and gas sector should considerably promote the successful implementation of tasks set before the sector. Such strategic partnership experience has already existed. Owing to big capital investments in reconstruction and

${ }^{19}$ Liu Chun Yong. 2005. Oil and gas introduction of Central Asian Countries. Central Asia News 
modernization of the Turkmenbashy Complex of Oil Refineries (US\$ 1.5 billion) new processing lines such as hydro treatment and catalytic reforming and catalytic cracking plants, high-octane and environmentally friendly gasoline and lubricants production facilities and polypropylene production units have been put into operation. These facilities have no analogues in the region by their technical features. The pace, methods and means of comprehensive restructuring of the oil and gas sector should facilitate the successful realization of grandiose plans of the country's economic development. 20

\subsubsection{Oil and gas development strategy of Uzbekistan}

Uzbekistan's oil and gas resources account for 30 per cent and 70 per cent of oil and gas of Central Asia. The government tries to rope in huge amount of foreign capital to develop these industries. This will prove to be a major boost to Uzbekistan economy. Joint ventures are being encouraged for setting up of oil and natural gas industry in Uzbekistan.

Russia has pumped in a lot of capital in the natural gas industry of Uzbekistan. The domestic company Uzbekneflegaz has signed an agreement with Itera, a Russian company for exploration and development of new natural gas reserves. Trinity Energy of Britain has invested large amount of capital in increasing production of natural gas in the country. Uzbekistan is a major exporter of oil and natural gas to its neighbouring countries like Kazakhstan, Kyrgyzstan, Russia, Ukraine and Tajikistan. The Mubarak gas processing plant is the largest in the country. ${ }^{21}$

\section{Shanghai Cooperation Organization: Strategic platform for energy cooperation.}

There is a close supply and demand complementarity between the energy sector of China and Central Asian countries. To establish an effective strategic platform for energy cooperation will play an important role in deepening bilateral energy cooperation, implementing China's energy import diversification strategy and the Central Asian country's energy export diversification strategy effectively. Shanghai Cooperation Organization is a platform to play this role.

It was founded in Shanghai on June15, 2001, by six countries: China, Russia, Kazakhstan, Kyrgyzstan, Tajikistan and Uzbekistan.

The purpose of the organization is: to strengthen the mutual trust between member countries; to encourage effective cooperation in the political, economic and trade, science and technology, culture, education, transportation, environmental protection and other fields between each member countries; to work together to maintain and safeguard regional peace, security and stability; to establish a democratic, fair and reasonable new international political and economic order. Since its establishment, the Shanghai Cooperation Organization has played an important role in fighting against drug crime and international terrorism, has built a relatively stable regional environment, and has laid a foundation for the economic and social development.

From the development perspective, the economic cooperation is the main driving factor of the development of this organization, and also the important source of strengthening mutual dependence. Because of the energy advantage of Central Asian countries and China's increasing demand for petroleum, natural gas and other energy resources, the energy cooperation constitutes

\footnotetext{
${ }^{20}$ http://www.turkmenistaninfo.ru/?page_id=6\&type=article\&elem_id=page_6/magazine_33/262\&lang_id=en

${ }^{21} \underline{\text { http://www.mapsofworld.com/uzbekistan/economy-and-business/uzbekistan-oil-and-gas.html }}$
} 
the most important content and characteristic of energy cooperation in regional economic cooperation of Shanghai cooperation organization.

In five Central Asian countries, there are four members of Shanghai cooperation organization. As an important platform of China and Central Asian countries interaction, the Shanghai cooperation organization is the most important institutional arrangement for coordinating policy interests of each side. In deepening energy cooperation, China and Central Asian countries could use this platform, to establish mutually beneficial win-win energy cooperation mechanism.

\section{Conclusions}

China is adjacent to Five Central Asian Countries, this provides natural geographic advantages to deepen oil and gas cooperation for both sides. Central Asian countries have rich resources and energy, they are currently looking for a way out and market, and the rapid development of Chinese economy has very big energy demand. Deepening energy cooperation between China and Central Asia is not only the need of China, but also the need of Central Asian countries. Political, economic, military cooperation provided experience for further energy cooperation.

In order to meet the requirements of domestic economic development, China made energy import strategy and "going out" strategy for new century. In order to promote national economic and social development the Central Asian countries have also developed the energy strategy and energy export strategy. Both strategies have very strong complementarities. Shanghai Cooperation Organization provided a good platform for the implementation of the energy strategy. Therefore, deepening energy cooperation between China and Central Asia, and seeking the propulsion mode of energy cooperation between China and Central Asia, is not only feasible in theory, but also has the important practical significance.

\section{References:}

[1]BP Statistical Review of World Energy, June 2016 and CIA World Fact Book 2016.

[2]WanZhihong “CNPC inks deal with Uzbekistan” China Daily, June 10, 2010, available online at http://www.chinadaily.com.cn/business/2010-06/11/content_9964779.htm

[3] Le Tian, “Turkmenistan Energy Deals Signed,” China Daily, July 18, 2007, available online at http://www.chinadaily.com.cn/china/2007-07/18/content_5438174.htm;

[4]Daniel Kimmage, “Central Asia: Turkmenistan-China Pipeline Project Has Far-Reaching Implications,” Radio Free Europe/RadioLiberty, April 10, 2006, available online at http://www.rferl.org/content/article/1067535.html.

[5] Hogan, M. (1997), Energy - economy interactions: The fable of the elephant and the rabbitworking paper, EMF No. 1.3, Energy Modeling Forum, Stanford.

[6] Central Asian Oil and Gas Pipelines, http://www.worldpress.org/specials/pp/pipelines.htm

[7] Central Asia Energy Data, Statistics and Analysis. http://www.eia.doe.gov/cabs/Centasia/Background.html

[8] Andrew E. Kramer. Central Asia on Front Line in Energy Battle. The New York Times, December 20， 2007

[9] John Chan. China pushes into Central Asia for oil and gas. World Socialist Web Site, 3 January 2001 http://www.wsws.org/articles/2001/jan2001/oil-j03.shtml 
[10] CAC > Energy and Materials > Oil \& Gas http://www.centralasiacommerce.com/energy/oilgas.htm

[11]Fazilov F, Chen X. China and Central Asia: A Signiicant New Energy Nexus[J]. Central Asia, 2013(4-5):38-43.

[12]Wrobel R. China’s New Energy Geopolitics: The Shanghai Cooperation Organization and Central Asia[J]. Econstor Open Access Articles, 2014. 